\title{
IS THIS THE COLLAPSE OF ISLAMIC STATE? THE EVOLUTION OF THE TERRORIST THREAT IN THE MIDDLE EAST IN 2017
}

The main purpose of this study is to analyze the major determinants and changes in terrorist activity in the Middle East in 2017. An analysis of the activity of terrorist organizations in the area will also be carried out, and a forecast of trends in the use of terrorist tactics in the short- and medium-term will be produced.

Given the current discourse on the nature of modern terrorism and the number of different perceptions of terrorism, the definition by A.P. Schmid has been adopted as the main point of reference, which says that terrorism is "an anxiety-inspiring method of repeated violent action, employed by (semi-)clandestine individual, group, or state actors, for idiosyncratic, criminal or political reasons, whereby - in contrast to assassination - the direct targets of violence are not the main targets. The immediate human victims of violence are generally chosen randomly (targets of opportunity) or selectively (representative or symbolic targets) from a target population and serve as message generators. Threat- and violence-based communication processes between terrorist (organization), (imperiled) victims, and main target are used to manipulate the main target (audience(s)), turning it into a target of terror, a target of demands, or a target of attention, depending on whether intimidation, coercion, or propaganda is primarily sought" (Schmid, Jongman, 2005: 28). In line with the above, it is not terrorism when violent acts are perpetrated involving damage to property (although, in this case, a political motivation may be suggestive of a terrorist attack); attacks against military infrastructure (warships, military aircraft, buildings used by the military); attacks against the police and infrastructure used by the police during armed conflicts (even when collateral damage involves civilians); attacks against secular or religious symbols, unless civilians are also the target of such acts (thus attacking the building of a church, synagogue or mosque without any casualties is not a terrorist act); direct homicide (involving a single victim) in which the perpetrator does not make any political claims regarding the killing, as opposed to a situation involving more victims when a mass murder draws the attention of a wider audience on account of its political motivation; the use of violence during armed conflicts or guerrilla activity which does not qualify as a war crime, crime against humanity or violation of the law of armed conflict; violent acts permitted by the right of legally elected authorities to use violence in order to restore social order in a manner adequate to the existing threat and applied within the limits of binding legislation; or the spontaneous use of violence for political 
reasons, such as demonstrations and other forms of public protest (e.g. revolutions) (Schmid, 2011: 84).

Among the many terms used in this article, two deserve special attention, namely individual terrorism and individual terrorist. They are used relatively infrequently in literature on the subject because terrorist activity is typically associated with terrorist groups. The two terms may be understood either in a broad or narrow sense. In the broad sense, individual terrorism means any terrorist activity undertaken by individuals operating either outside of or in association with a terrorist organization. In the narrow sense of the term, individual terrorism means exclusively terrorist activity undertaken by individuals who are in no way associated with any terrorist organizations (Wejkszner, 2018: 33-34).

\section{MAJOR FACTORS LEADING TO TERRORIST ACTIVITY IN THE MIDDLE EAST}

The major factors leading to the expansion of terrorism include politico-historical (Byman, 2007: 10-14; Madej, 2001: 53-57), cultural and religious (Richardson, 2006: 142, 167), socio-economic (Ehrlich, Liu, 2002: 183-192) and technological reasons (Adamski, 2007: 7-8). The above classification is useful for the analysis of the sources of terrorism in the Middle East as long as the first two groups of reasons are given primacy. The politico-historical sources of terrorism in the Middle East are closely related to nationalism on the one hand (the dychotomic approach to this ideological perspective partly explains the essence of the Israeli-Palestinian dispute) and imperialism on the other (the domination and involvement of hegemonic states in the region had a detrimental impact on the social, economic and political situation of its residents). The socio-economic sources of terrorism in the Middle East in turn are closely related to the mobilization of social groups committed to achieving certain political goals via non-standard methods (such as violence, in particular involving suicide attacks). Some researchers are of the opinion that the economic deprivation and social marginalization of large groups in Middle Eastern society is a significant prerequisite for the emergence of ethnic-religious terrorism. However, the development of the most recent wave of terrorism in the area was triggered by cultural and religious factors. Islamic and Jewish fundamentalisms have clearly left their mark on the evolution of religious terrorism and resulted in the emergence of numerous more or less recognizable terrorist groups (Krawczyk, 2007: 59-68, 80-108).

\section{REVIEW OF TERRORIST ORGANIZATIONS ACTIVE IN THE MIDDLE EAST}

The Middle East is without a doubt witnessing the vigorous and multifarious development of terrorism. In recent decades more than a dozen significant terrorist groups have emerged, inspired by different ideologies and frequently fighting for very different (frequently clashing) causes, which sometimes co-exist or, more frequently, fight 
with one another. These can be secular, sometimes nationalist groups, as well as those emphasizing religious claims. An example of the former are Kurdish terrorist groups, embodied by the Kurdistan Workers' Party (PKK) and associated hit squads, as well as the Kurdistan Freedom Hawks (TAK). The latter is exemplified by jihadist organizations such as Islamic State (IS) or the al-Qaeda Central Command (AQC) and the associated regional terrorist networks, such as the al-Nusra Front (NF), which severed its relations with the AQC and in early 2017 changed its name to Hayat Tahrir al-Sham (HTS), and al-Qaeda in the Arabian Peninsula (AQAP). The analysis of terrorist activity in 2017 leads to the conclusion that Palestinian organizations (Hamas and Hezbollah) were practically inactive in terms of terrorist operations in this period. This is not to say that a number of terrorist acts carried out in Israel and Palestine by individual terrorists lacked support.

\section{CHRONOLOGICAL ANALYSIS OF TERRORIST ACTIVITY IN THE MIDDLE EAST}

\section{The Twilight of the Islamic (Proto)State and the Rise in Terrorist Activity}

Islamic State entered a critical period in 2017. The proto-state structures that had gradually been set up by its predecessor were doomed to collapse right from the outset. Similar structures have existed before (Wejkszner, 2016: 41-45), but none of these projects lasted longer than a year or so. The asymmetrical combat against local enemies, using guerrilla tactics first and foremost (such as attacks on Iranian and Syrian uniformed services by small groups of fighters), and the inability to stand up to the might of external powers (including Russia and the United States) were of essential importance in the fate of the revived caliphate.

Three essential issues were interesting regarding the operations of Islamic State as a sui generis terrorist organization. One was its opting for the tactic of individual jihadist terrorism (Wejkszner, 2018). The second involved timid attempts to feminize terrorist activity (Winter, Margolin, 2017: 23). Both of these tactical solutions were successfully used in the period analyzed, both in and outside of the Middle East, which suggests that Islamic State was searching for new forms of operational activity given its advancing structural dissolution. The third factor, related to this, was the gradual reduction of the number of foreign fighters in the ranks of Islamic State in the Middle East. Some of them were physically eliminated due to the anti-terrorist actions by the Iraqi and Syrian governments aided by their foreign partners. Other fighters gave up active combat and decided to return to their respective countries of origin. These adverse developments have not deterred the IS fighters continuing their terrorist campaign, or in some cases have mobilized them even more.

The range of activities carried out by Islamic State involved the successful use of suicide attacks, in particular simultaneous attacks by small groups of fighters. This is exemplified by a series of terrorist attacks in Baghdad, such as the attack of January 2, which killed over 50 and injured a further 120 people (NYT, 2017) or the attack of 
January 8, 2017 (ALJAZEERA, 2017a). Similar attacks took place in Baghdad and Mosul on February 10, 2017 (TODAY, 2017). Further simultaneous attacks were carried out in Baghdad on February 15 (Adel, 2017a); in Susiyan, Syria, on February 24 (Persio, 2017); near Kirkut on February 25 (REUTERS, 2017b); in Tikrit on March 8 (DW, 2017); in Damascus on March 15 (ALJAZEERA, 2017b); in Baghdad on April 5, May 20, August 8 and September 7, 2017 (al-Hassani, Amir, 2017; Mostafa, 2017f; Mostafa, 2017h; Mostafa, 2017i); and near an-Nasiriyah in Iraq on September 14, 2017 (BBC, 2017b). Another spectacular simultaneous attack was carried out on October 12, 2017, in a Syrian refugee camp near Deir ez-Zor which killed 50 and injured a further 70 people (REUTERS, 2017e). One month later, a series of further suicide attacks was launched in the Syrian governorate of Deir ez-Zor (LE FIGARO, 2017).

The tactic of suicide attacks continued with the use of motor vehicles (e.g. in Baghdad on March 20 (ALJAZEERA, 2017c)); in some bomb attacks, the explosives were planted in cars and remotely activated (Baghdad, May 11 (Mostafa, 2017e) and May 30, 2017 (Tawfeeq, 2017)). Some attacks using motor vehicles were a manifestation of urban guerrilla warfare, as evidenced by an attack against a police control point in Baghdad on March 29, 2017 (ALJAZEERA, 2017d) or in Tikrit on April 5, 2017 (REUTERS, 2017c). Classical suicide attacks carried out by terrorists carrying explosives on their bodies are exemplified by the attacks on Christian churches in Alexandria and Tanta in Egypt on April 9, 2017 (Gaballa, Tolba, 2017), and an attack in al-Musayyib, Iraq, on June 9, 2017 (Iraq, 2017). A similar tactic, combined with the use of light weapons and camouflage (dressing up as a woman) was also applied by IS terrorists in Tehran on June 7, 2017 (BBC, 2017a). Camouflage was sometimes unnecessary since women were the actual attackers, as was the case in an attack in Karbala, Iraq, on June 9, 2017 (Mostafa, 2017g).

A novel tactic that was used increasingly often was the use of drones carrying explosives to launch the attacks. Such a solution was used, among other locations, in Mosul on January 20 (Mostafa, 2017a), February 15 (Mostafa, 2017b) and on February 20, 2017 (Mostafa, 2017c).

IS terrorists did not hesitate to use chemical weapons to attack civilians, as exemplified by the attack in Mosul on March 1, 2017. According to official reports, the jihadists used mustard gas (Adel, 2017b). A similar attack was launched less than a week later near Mosul (Adel, 2017c).

\section{Regional Terrorist Networks Associated With Al-Qaeda and the Gradual Abandonment of Terrorist Activity}

Al-Qaeda in the Arabian Peninsula (AQAP) is one of the most important regional structures within the global Al-Qaeda network (Wejkszner, 2017: 146-148). Until 2017, AQAP was highly involved in building local proto-state structures. The main means to this end involved guerrilla warfare, including attacks against military and police forces in Yemen. The majority of these attacks were reported by the media as terrorist acts, which was not the case if we apply the methodology adopted in this paper (e.g. the attack in Zinjibar, Yemen, on February 24 (REUTERS, 2017a) and March 5, 2017 
(Hussein, 2017), or the suicide attack on a police control point in Shabwa, Yemen, on August 3, 2017 (REUTERS, 2017d)).

The external pressure on the Al-Nusra Front in 2016 accelerated the integration processes of jihadist opposition participating in the conflict in Syria. In late July 2016, the group changed its name and announced its severance of operational relations with al-Qaeda. This was primarily done for propaganda and tactical purposes (Lister, 2018: 2-4) since the group was trying to shake its image of a terrorist organization and emphasize its operational independence in its pursuit of the Islamic order being implemented. This was further confirmed on January 28, 2017 by the unification of the AlNusra Front and the Ansar al-Din Front, Nour al-Din al-Zenki Movement and groups of Jaysh al-Sunna and Liwa al-Haqq, which led to the establishment of the Hayat Tahrir al-Sham (Organization for the Liberation of the Levant). One of the main reasons for their integration was the desire to lay the organizational foundations for a future emirate to be established in Syria, a strategic goal to be achieved by the end of 2017. The main obstacle to this goal was the Syrian regime, additionally aided by foreign powers (in particular Russia and Iran). Hayat Tahrir al-Sham formally severed its links with al-Qaeda but it fully approved of its asymmetrical modus operandi, namely guerrilla warfare and sporadic terrorist attacks. It opted for the former while trying to protect civilians as much as possible, in order to win their sympathy. Terrorist attacks actually ceased throughout the territory controlled by the group. They were only launched in enemy territory, the embodiment of which was a spectacular simultaneous suicide attack carried out in Damascus, Syria, on March 11, 2017 (DNA, 2017).

\section{Kurdish Terrorism vis-a-vis the Turkish Threat}

Kurdish terrorists gave their ultimate response to mass attacks against the Kurdish population by the Turkish Army. This terrorist activity may be exemplified by the attack carried out in Izmir on January 5, 2017, by the Kurdistan Freedom Hawks (Teyrêbazên Azadiya Kurdistan, TAK, a faction that split from the Kurdistan Workers' Party (PKK) in 2004). They attacked by planting a load of powerful explosives in a motor vehicle in front of a court of justice and firing at the building with light weapons (DHA, 2017). PKK terrorist cells were also active. Members of one such cell detonated an explosive load under a civilian vehicle carrying workers hired by the municipal authorities of Sirnak, Turkey, on January 16, 2017 (Explosive, 2017). A similar attack occurred on August 14, 2017 in a district of Semdinli in the Hakkari province in Turkey (Kazandioglu, Karadeniz, 2017). Nevertheless, guerrilla tactics were employed much more often, attacking small patrols or Turkish military convoys.

\section{Examples of Individual Terrorist Tactics in yhe Middle East}

The quantitative analysis of terrorist activity in the Middle East and its perpetrators in 2017 leads to the conclusion that the tactic of individual terrorism was one of the many forms of asymmetrical warfare practiced there. Examples show that it was primarily 
used by Palestinians fighting against Israel and by jihadists from Islamic State. Bearing in mind the typology discussed at the beginning of this paper, individual terrorism needs to be examined both in its narrow and broad sense.

Regarding Palestinians, a number of terrorist attacks can be mentioned that were carried out in Jerusalem (i24NEWS, 2017a; Beaumont, 2017) and Tel Aviv (i24NEWS, 2017b) against civilians from Israel or the United States. Numerous attacks were also launched against members of the uniformed services (mainly the police), but these should be classed as somewhat anarchic urban guerrilla warfare. Individual jihadists associated with Islamic State used this tactic (in its broader sense), for instance in Mosul on April 18 (Mostafa, 2017d) or Hurghada on July 14, 2017 (Abdellah, Tolba, 2017). In the latter case, the terrorist attacked foreign tourists. Yet individual foreign fighters from Islamic State attacked military targets more often. One example of this is the attack launched by a jihadist from Germany near al-Bahra, province of Deir ez-Zor, Syria, on December 31, 2017 (Illingworth, 2018).

\section{FORECAST OF TERRORIST ACTIVITY IN THE MIDDLE EAST}

The collapse of Islamic State (which was actually a proto-state) should not be equated with the breakdown of the terrorist organizational structures. Throughout the entire period of its existence, IS has been expanding its terrorist network outside the Middle East, which has made it possible for it to continue its disruptive impact on the states known to jihadist ideologists as the 'close enemies.' It is therefore unlikely that the threat from this group will be eliminated or even considerably limited in a short- or medium-term. In developing and analyzing a prediction of the actions of this group over a longer period of time, one should consider at least two possible scenarios; both the gradual disintegration of the structures of Islamic State, which should translate into a noticeable decline in terrorist activity, or the evolution of its organizational structure and possible resumption of the development of proto-state structures (in favorable regional and global circumstances), which may be accompanied by intensified terrorist activity.

The activity of the remaining terrorist organizations, in the short- or medium-term, will probably remain at the current level. Analysis of the available data on the frequency of terrorist attacks, as well as the combination of terrorist and guerrilla tactics (as is the case of al-Qaeda in the Arabian Peninsula), supports the assumption that the number of attacks will also remain constant, although this trend will be closely related to the internal situation of the states in the region. A low-intensity conflict with Kurdish terrorist groups is likely to continue in Iraq, Syria and Turkey. The activity of these groups will be closely related to the counter-terrorist activity of the Turkish special forces and the army. If the pressure from these forces continues to grow, the number of terrorist or guerrilla attacks by Kurdish groups is likely to remain constant or even increase slightly.

If the peace process in the Middle East does not advance, meaning that an independent Palestinian state will not be established, further asymmetrical Palestinian activity may be expected. Palestinians are likely to continue to implement the two 
complementary tactics of individual and suicide terrorism. Since the resolution of this issue does not seem likely, asymmetrical operations will probably continue to be a permanent element of Palestinian political strife in the future.

It can be concluded that terrorism (and guerrilla warfare, which accompanies terrorism) will continue to have an adverse impact on socio-political relations in this part of the world.

\section{REFERENCES}

Abdellah M., Tolba A. (2017), Two German tourists stabbed to death on Egyptian beach, Reuters, 14.07.2017, https://www.reuters.com/article/us-egypt-security-tourists/two-german-touristsstabbed-to-death-on-egyptian-beach-idUSKBN19Z1KW (23.03.2018).

Adamski J. (2007), Nowe technologie w stużbie terrorystów, Warszawa.

Adel L. (2017a), Car bomb blast in Habibiya near Baghdad leaves 25 casualties, „Iraqi News”, 15.02.2017, https://www.iraqinews.com/iraq-war/car-bomb-blast-habibiya-near-baghdadleaves-25-casualties/> (23.03.2018).

Adel L. (2017b), Mosul victims treated for chemical agents as displacement accelerates, „Iraqi News”, 4.03.2017, https://www.iraqinews.com/iraq-war/mosul-victims-treated-chemicalagents-displacement-accelerates/ (12.03.2018).

Adel L. (2017c), IS chemical missiles kill 4 civilians and wounds 25 others near Mosul, „Iraqi News”, 6.03.2017, https://www.iraqinews.com/iraq-war/chemical-missiles-kill-4-civilians-wounds25-others-near-mosul/ (23.03.2018).

ALJAZEERA (2017a), Iraq: Suicide attacks rock Baghdad killing at least 20, „Al Jazeera”, 8.01.2017, https://www.aljazeera.com/news/2017/01/iraq-suicide-attacks-rock-baghdadkilling-20-170108131406836.html (23.03.2018).

ALJAZEERA (2017b), Syria war: Twin suicide attacks kill dozens in Damascus, 15.03.2017, https:// www.aljazeera.com/news/2017/03/suicide-attack-hits-justice-palace-syria-damascus170315114623986.html (13.03.2018).

ALJAZEERA (2017c), Baghdad car bomb kills at least 21, Al Jazeera, 21.03.2017, https:// www.aljazeera.com/news/2017/03/car-bomb-kills-23-baghdad-170320175853000.html (23.03.2018).

ALJAZEERA (2017), Suicide truck bomber kills 17 in Baghdad, Al Jazeera, 30.03.2017, https:// www.aljazeera.com/news/2017/03/suicide-oil-tanker-bomber-kills-15-baghdad170329211917253.html (23.03.2018).

BBC (2017a), Iran attacks: 'IS' hits parliament and Khomeini mausoleum, BBC News, 7.06.2017, https://www.bbc.com/news/world-middle-east-40184641 (23.03.2018).

BBC (2017b), Iraq: At least 60 die in twin attacks near Nasiriya, BBC News, 14.09.2017, https:// www.bbc.com/news/world-middle-east-41270791 (15.03.2018).

Beaumont P. (2017), Jerusalem stabbing: British student, 20, killed close to Old City, „The Guardian", 14.04.2017, https://www.theguardian.com/world/2017/apr/14/british-woman-stabbedto-death-in-jerusalem-good-friday (23.03.2018).

Byman D. (2007), Deadly Connections. States that Sponsor Terrorism, New York.

Byman D. L. (2017), The Islamic State's long-term threat to the Middle East, Brookings, 28.07.2017, https://www.brookings.edu/blog/markaz/2017/07/28/the-islamic-states-long-term-threat-tothe-middle-east/ (13.01.2018). 
DHA (2017), İmir'deki alçak saldırıyı TAK üstlendi, Dogan Haber Ajansi, 11.01.2017, http://arsiv. dha.com.tr/izmirdeki-alcak-saldiriyi-tak-ustlendi_1433394.html (12.03.2018).

DNA (2017), Twin bombings in Damascus kill 59, mostly Iraqi pilgrims, DNA, 12.03.2017, http:// www.dnaindia.com/world/report-twin-damascus-bombs-kill-59-mostly-iraqi-pilgrims2350570 (12.03.2018).

DW (2017), Scores killed in twin suicide attack on Iraq wedding, Deutsche Welle, 8.03.2017, https:// www.dw.com/en/scores-killed-in-twin-suicide-attack-on-iraq-wedding/a-37862326 (12.03.2018).

Ehrlih P. R., Liu J. (2002), Some Roots of Terrorism, „Population and Environment”, Vol. 24, No. 2. Explosive detonated by PKK wounds 5 in Şirnak, Turkey (2017), „Yeni Safak”, 16.01.2018, https:// www.yenisafak.com/en/news/explosive-detonated-by-pkk-wounds-5-in-sirnak-turkey2597726 (marzec 2018)

Gaballa A., Tolba A. (2017), Palm Sunday bombings of Egyptian Coptic churches kill 44, Reuters, 9.04.2017, https://www.reuters.com/article/us-egypt-violence-idUSKBN17B06U?il=0 (12.03.2018).

al-Hassani A., Amir H. (2017), Bomb attacks kill 9 in Iraq, Anadolu Agency, 5.04.2017, https://www. aa.com.tr/en/middle-east/bomb-attacks-kill-9-in-iraq/789579 (12.03.2018).

Horton M. (2017), Fighting the Long War: The Evolution of al-Qa ida in the Arabian Peninsula, „CTC Sentinel”, Vol. 10, Issue 1, January.

Hussein S. (2017), 6 killed in al-Qaeda attack in southern Yemen, Anadolu Agency, 5.03.2017, https:// www.aa.com.tr/en/middle-east/6-killed-in-al-qaeda-attack-in-southern-yemen/764499 (12.03.2018).

Illingworth A. (2018), Huge ISIS bombing in east Syria by German jihadist leaves nearly 100 USbacked fighters killed, wounded, AMIN, 1.01.2018, https://www.almasdarnews.com/article/ huge-isis-bombing-east-syria-german-jihadist-leaves-nearly-100-us-backed-fighters-killedwounded/ (12.03.2018).

Iraq blast: Suicide bomber kills 30 Shias near Karbala, Islamic State claims responsibility (2017), „Hindustan Times”, 9.06.2017, https://www.hindustantimes.com/world-news/suicide-bomber-kills-20-in-iraq-islamic-state-claims-responsibility/story-vtKbcwmusZ3Sq7uxCy7bFO. html (12.03.2018).

i24NEWS (2017a), Three wounded in stabbing attack in Old City of Jerusalem, i24 News, 1.04.2017, https://www.i24news.tv/en/news/israel/141639-170401-initial-report-of-stabbing-in-oldcity-of-jerusalem (12.03.2018).

i24NEWS (2017b), Terror attack near Tel Aviv beachfront wounds four, i24 News, 23.04.2017, https:// www.i24news.tv/en/news/israel/143439-170423-four-injured-in-suspected-stabbing-near-atel-aviv-beach (12.03.2018).

Kazandioglu Y., Karadeniz S. (2017), 2 killed in PKK terror attack in SE Turkey, Anadolu Agency, 14.08.2017, https://www.aa.com.tr/en/turkey/2-killed-in-pkk-terror-attack-in-se-turkey/ 884145 (12.03.2018).

Krawczyk A. (2007), Terroryzm ugrupowań fundamentalistycznych na obszarze Izraela $w$ drugiej polowie $X X$ wieku, Torun.

LE FIGARO (2017), Actualité Flash Actu Syrie: 26 morts dans un attentat de l'EI, „Le Figaro”, 17.11.2017, http://www.lefigaro.fr/flash-actu/2017/11/17/97001-20171117FILWWW00295syrie-26-morts-dans-un-attentat-de-l-ei.php (12.03.2018).

Lister C. (2018), How al-Qa ida Lost Control of its Syrian Affiliate: The Inside Story, „CTC Sentinel", Vol. 11, Issue 2, February.

Madej M. (2001), Międzynarodowy terroryzm polityczny, Warszawa. 
Mostafa N. (2017a), Elder, grandson killed by bomb from Islamic State-guided drone in Mosul, „Iraqi News", 20.01.2017, https:/www.iraqinews.com/iraq-war/elder-grandson-killed-bombislamic-state-guided-drone-mosul/ (12.03.2018).

Mostafa N. (2017b), Three civilians killed as IS drones bomb eastern Mosul market, „Iraqi News”, 15.02.2017, https://www.iraqinews.com/iraq-war/three-civilians-killed-drones-bomb-eastern-mosul-market (12.03.2018).

Mostafa N. (2017c), Islamic State drones, rockets kill 11 civilians, including school kids, in eastern Mosul, ,Iraqi News”, 21.02.2017, https://www.iraqinews.com/iraq-war/islamic-state-dronesrockets-kill-11-civilians-including-school-kids-eastern-mosul/ (12.03.2018).

Mostafa N. (2017d), IS attack kills 16 civilians in western Mosul, „Iraqi News”, 8.04.2017, https:// www.iraqinews.com/features/attack-kills-16-civilians-western-mosul/ (12.03.2018).

Mostafa N. (2017e), Four killed, 10 wounded in a Shiite-majority district blast, eastern Baghdad, „Iraqi News”, 11.05.2017, https://www.iraqinews.com/iraq-war/four-killed-10-woundedshiite-majority-district-blast-eastern-baghdad/ (12.03.2018).

Mostafa N. (2017f), More than 80 killed, injured in several Baghdad, Basra blasts, „Iraqi News”, 20.05.2017, https://www.iraqinews.com/iraq-war/80-killed-injured-several-baghdad-basrablasts/ (12.03.2018).

Mostafa N. (2017g), Woman detonates bomb in crowded Friday market in Iraq, killing at least 30, „Iraqi News”, 9.06.2017, https://www.iraqinews.com/iraq-war/woman-detonates-bombcrowded-friday-market-iraq-killing-least-30/ (12.03.2018).

Mostafa N. (2017h), 25 civilians killed, injured in two blasts at south, east of Baghdad, „Iraqi News”, 28.08.2017, https://www.iraqinews.com/iraq-war/25-civilians-killed-injured-two-blastssouth-east-baghdad/ (12.03.2018).

Mostafa N. (2017i), Civilian killed, 4 wounded in bomb blast south of Baghdad, „Iraqi News”, 7.09.2017, https://www.iraqinews.com/iraq-war/civilian-killed-4-wounded-bomb-blastsouth-baghdad-3/ (12.03.2018).

NYT (2017), Suicide Bombing in Baghdad Kills at Least 36, „The New York Times”, 2.01.2017, https://www.nytimes.com/2017/01/02/world/middleeast/iraq-baghdad-market-suicidebombing-islamic-state.html (12.03.2018).

Persio S. O. (2017), Isis targets civilians returning to liberated al-Bab in deadly Syrian car bomb attack, „International Business Times”, 24.02.2017, https://www.ibtimes.co.uk/isis-targetscivilians-returning-liberated-al-bab-deadly-syrian-car-bomb-attack-1608360 (12.03.2018).

REUTERS (2017a), Suicide bomber kills at least eight soldiers in Yemen's Zinjibar, Reuters, 24.02.2017, https://www.reuters.com/article/us-yemen-security/suicide-bomber-kills-atleast-eight-soldiers-in-yemens-zinjibar-idUSKBN1630LR (12.01.2018).

REUTERS (2017b), Bombs target oil pipeline in Iraq's Kirkuk, one killed, Reuters, 25.02.2017, https://www.reuters.com/article/us-mideast-crisis-iraq-blast-idUSKBN164074> (12.03.2018).

REUTERS (2017c), Islamic State kills 31 in Iraq's Tikrit: security sources, medics, Reuters, 5.04.2017, https://www.reuters.com/article/us-mideast-crisis-iraq-tikrit-idUSKBN1770KD?il=0> (12.03.2018).

REUTERS (2017d), Yemen suicide car bomb kills 5 soldiers: residents, Reuters, 3.08.2017, https:// www.reuters.com/article/us-yemen-security-idUSKBN1AJ0MI (12.03.2018).

REUTERS (2017e), Islamic State attacks kill at least 50 in east Syria: Kurdish Red Crescent, Reuters, 12.10.2017, https://www.reuters.com/article/us-mideast-crisis-syria-attack/islamicstate-attacks-kill-at-least-18-in-eastern-syria-monitor-idUSKBN1CH2RI (marzec 2018).

Richardson L. (2006), The Roots of Terrorism, New York-London. 
Schmid A. P. (2011), The Routledge handbook of terrorism research, London-New York.

Schmid A. P., Jongman A. J. (2005), Political Terrorism. A New Guide to Actors, Authors, Concepts, Data Bases, Theories \& Literature, New Brunswick-London.

Strack C. (2017), The Evolution of the Islamic State's Chemical Weapons Efforts, „CTC Sentinel”, Vol. 10, Issue 9, September.

al-Tamimi A. (2017), The Formation of Hay'at Tahrir al-Sham and Wider Tensions in the Syrian Insurgency, „CTC Sentinel”, Vol. 10, Issue 2, February.

Tawfeeq M. (2017), ISIS targets Iraqi families with blast at Baghdad ice cream shop, CNN, 30.05.2017, https://edition.cnn.com/2017/05/29/world/iraq-baghdad-car-bomb/index.html (12.03.2018).

TODAY (2017), Suicide bombings kill 10, wound 33 in Mosul, Baghdad, „Today Online”, 13.02.2017, https://www.todayonline.com/world/suicide-bombing-kills-four-wounds-15-eastern-mosulrestaurant (12.01.2018).

Wejkszner A. (2016), Państwo islamskie. Narodziny nowego kalifatu?, Warszawa.

Wejkszner A. (2017), Globalna sieć Al-Kaidy. Nowe państwo islamskie?, Warszawa.

Wejkszner A. (2018), Samotne wilki kalifatu? Państwo Islamskie i indywidualny terroryzm dżihadystyczny w Europie Zachodniej, Warszawa.

Winter C., Margolin D. (2017), The Mujahidat Dilemma: Female Combatants and the Islamic State, "CTC Sentinel", Vol. 10, Issue 7, August.

Yeo W. (2017), Four trends in global terrorism threats in 2017, "The Straits Times", 10.01.2017, http://www.straitstimes.com/opinion/four-trends-in-global-terrorism-threats-in-2017 (12.01.2018).

\begin{abstract}
The main aim of this article is to present an evolution of the terrorism threat in the Middle East in 2016. For this purpose, firstly, the essence and determinants of the contemporary terrorism threat have been analyzed. Some main Middle East terrorist organizations, actively operating in this area, have also been indicated. Secondly, the chronology and the most important terrorism trends in the region have been presented. A special attention has been paid to consequences of the fall of the Islamic State. And last but not least some predictive scenarios regarding the development of above phenomenon in 2017 and beyond have been pointed out.
\end{abstract}

Keywords: Middle East, terrorism, evolution, Al-Qaeda, Al-Qaeda in the Arabian Peninsula, Islamic State, proto-state, jihad

\title{
UPADEK PAŃSTWA ISLAMSKIEGO? EWOLUCJA ZAGROŻENIA TERRORYSTYCZNEGO NA BLISKIM WSCHODZIE W 2017 ROKU
}

\section{STRESZCZENIE}

Przedmiotem rozważań w niniejszym artykule jest problematyka ewolucji zagrożenia terrorystycznego na Bliskim Wschodzie w 2017 r. W tym celu analizie poddano, po pierwsze, istotę i kluczowe zagrożenia terrorystycznego, a także najważniejsze podmioty terrorystyczne aktywne na Bliskim Wschodzie. Po drugie, przedstawiono chronologię i najważniejsze trendy 
w ramach aktywności terrorystycznej w tym regionie. Szczególną uwagę zwrócono przy tym na konsekwencje upadku Państwa Islamskiego. I wreszcie, po trzecie, skupiono się na predykcji najważniejszych trendów rozwoju powyższego fenomenu w 2017 r. i kolejnych latach.

Słowa kluczowe: Bliski Wschód, terroryzm, ewolucja, Al-Kaida, Al-Kaida na Półwyspie Arabskim, Państwo Islamskie, protopaństwo, dżihad 
